\title{
Hemşirelerin Kanıta Dayalı Uygulamalara Yönelik Tutumlarının Belirlenmesi
}

\author{
Esra ŞADİ ŞEN* Seher YURT**
}

$\ddot{O} z$

Giriş: Kanıta dayalı uygulama, hemşirelik biliminde hızla artan araştırmaların ve araştırma sonuçlarının, klinik uygulamaya dönüştürülmesidir. Kanıta dayalı uygulamalar hemşirelerin otonomi kazanmaları için gerekli yetki arayışlarına yeni bir alternatif olmuştur. Amaç: Bu çalışmada, hemşirelerin kanıta dayalı hemşirelik uygulamalarına yönelik tutumlarının belirlenmesi amaçlandı. Yöntem: Tanımlayıcı olarak planlanan çalışmanın örneklemini, İstanbul'da bir vakıf üniversitesi hastanesinde çalışan 92 hemşire oluşturdu. Araştırma Şubat-Nisan 2019 tarihleri arasında yürütüldü. Verilerin toplanmasında Sosyodemografik Bilgi Formu ve 'Kanıta Dayalı Hemşireliğe Yönelik Tutum Ölçeği' kullanıldı, verilerin analizinde frekans, Kruskall Wallis testi ve Z skoru kullanıldı. Bulgular: Hemşirelerin \%21.7'si lisans mezunu olduğu, \%82.6'sının 10 yıldan az çalıştığı, \%91.3'ünün bilimsel yayınları takip etmediği, \%88'inin mesleki derneğe üye olmadığı, \%53.3'ünün kanıta dayalı uygulama dersi almadığı, \%88'inin bilimsel araştırmaya katılmadığ 1 ve \%62'sinin kanıta dayalı uygulamaya yönelik hizmet içi eğitim almadığ 1 belirlendi. Hemșirelerin 'Kanıta Dayalı Hemşireliğe Yönelik Tutum Ölçeği' toplam puan ortalaması $51.33 \pm 5.18$ bulundu. Öğrenim düzeyi, görev süresi, hizmet içi eğitim, bilimsel araştırmaya katılım ve kanıta dayalı uygulama dersi alma durumları arasında anlamlı fark olduğu tespit edildi $(p<0.05)$. Sonuç: Hemşirelerin kanıta dayalı hemşireliğe yönelik tutumları orta düzeyde bulunmuştur. Hemşirelerin kanıta dayalı uygulamaların yararlıığına inandıkları fakat kanıta dayalı inancın uygulamada davranış değişikliğine yol açmadığı sonucuna ulaşıldı. Araştırma sonuçları göz önüne alındığında; hemşirelere yönelik hizmet içi eğitim programlarında kanıta dayalı uygulamalara yer verilmesi, hastanelerde kanıta dayalı uygulama komitelerinin kurulması ve mentör hemşirelerin yetiştirilmesi, hastanelerin lisans ve lisansüstü hemşireleri daha fazla istihdam etmeleri önerilebilir.

Anahtar Sözcükler: Kanıta Dayalı Uygulama, Klinik Uygulama, Tutum.

\section{Abstract}

\section{Determining The Attitudes of Nurses Towards Evidence-Based Practices}

Background: Evidence-based practice is the transformation of rapidly increasing research in nursing science and the results of these research into practice in clinics.Evidence-based practices have become a new alternative to nurses' search for authority to gain autonomy. Aim: This study was aimed to determine the attitudes of nurses towards evidence-based nursing practices. Method:The sample of the study, which was planned as descriptive, consisted of 92 volunteers working at foundationuniversity hospital. The research was carried out between FebruaryApril 2019. Data were collected with 'Sociodemographic Information Form' and 'Evidence Based Nursing Attitude Scale'. Frequency, Kruskall Wallis test and Z test were used in the analysis of the data. Result: $21.7 \%$ of nurses were undergraduate, $82.6 \%$ were working under 10 years, $91.3 \%$ did not follow scientific publications, $88 \%$ were not members of professional associations. It was determined that $53.3 \%$ did not take evidence-based practice courses in education, $88 \%$ did not participate in scientific research and $62 \%$ did not receive in-service training for evidence-based practice in their institution. The total average scores of nurses' attitudes towards' Evidence Based Nursing' were found $51.33 \pm 5.18$. It was determined that there was a significant difference between nurses' education levels, duration of employment, in-service training, participation in scientific research, and taking an evidence-based practice courses $(p<.05)$. Conclusion: Nurses' attitudes towards evidence-based nursing were found to be moderate. It was concluded that the nurses believed in the usefulness of evidence-based practices, but evidence-based beliefs did not cause behavioral changes in practice. Considering the results of the research; Including evidence-based practices in in-service training programs for nurses, establishing evidence-based practice committees in hospitals, training mentor nurses, and employing more undergraduate and graduate nurses in hospitals may be suggested.

Key words: Evidence-Based Practice, Clinical Practice, Attitude.

Geliş tarihi: 15.05.2020 Kabul tarihi: 27.03.2021

$\mathrm{K}$ anıta Dayalı Uygulama (KDU); hemşirelik biliminde hızla artan araştırma sonuçları ile kanıtlanmış bilginin, klinik deneyimin yanı sıra bireyin gereksinim ve tercihleriyle bütünleştirilerek, bireyin yararına olacak şekilde hemşirelik uygulamalarına entegre edildiği bir problem çözme becerisidir $(1,2)$. Hemşireliğin içinde bulunduğu çağa ayak uydurmak için, belli araştırmalar ve yöntemler sonucunda üretilen ve aksi ispatlanıncaya kadar doğru kabul edilen bilgiyi, mesleki uygulamalarında kullanması kaçınılmazdır (3).

Günümüzde sağlık sistemi içinde sağlık bakımı alan hastanın, kendine yapılan her türlü işlemde bilgi alma isteği ve bilinci artmaktadır. Bu bağlamda yapılan her türlü işlemin bilimsel araştırmalara dayandırılması hem hukuki hem vicdanı anlamda kanıta dayalı uygulamaları zorunlu tutmuştur. Hemşirelerin bakımda ihmallerinin olması, yanlış tedavi uygulamaları, bilgi ve beceri eksiklikleri hastaya fiili zarar veren bir durumdur ve tıbbi hata olarak kabul edilir (4). Resmi gazete 8.3.201027515 maddesi ile hemşireler; "Bireyin, ailenin ve toplumun hemşirelik girişimlerini karşılayabilecek sağllkla ilgili ihtiyaçlarını belirleme ve hemşirelik tanılama çerçevesinde hemşirelik bakımını kanıta dayalı olarak planlar, uygular, değerlendirir ve denetler." şeklinde KDU yapılmasına vurgu yapmaktadır. Sağlık bakımından sorumlu hemşireler başta hemşirelik yasası olmak üzere, yönetmelik ve yasalara bağlı olarak sorumluluklarını tam olarak yerine getirmekle de yükümlüdür (5).

Kanıta dayalı uygulama kavramı sağlık sisteminde önemli bir konu olduğu halde, günümüzde hala birçok hemşire ve sağlık çalışanı tarafından yeteri kadar bilinmemektedir (6). Birçok ülke kanıta dayalı hemşireliği desteklemek adına farklı yapısal düzenlemeler ve roller üstlenmiştir (7). Hemşirelik mesleğinin lisans seviyesine yükselmesiyle, üniversitelerde ders olarak kanıta dayalı uygulamalara yer verilmeye başlanması ile beraber öğrencilerin literatür tarama ve KDU'lara inanma düzeylerinde artış olduğu görülmüştür (8). Literatürde, hemşirelerin araştırma bulgularını anlamadıkları araştırmalardan haberdar olmadıkları, araştırmalara inanmadıkları, araştırmaları okumadıkları ve klinikte kanıta dayalı uygulamaları hayata geçiren rol modeller bulamadıkları belirtilmektedir (9). Ayrıca, hemşirelerin yaptıkları uygulamalarda; \%75.5 oranında eğitimleri sırasında aldıkları bilgiyi, \%26.1 oranında kişisel deneyim ve \%4.0 oranında araştırma sonuçlarını kullandığı belirlenmiştir (10). Farklı bir araştırmada ise hemşirelerin uygulamada ki boşlukları belirleme ve delilleri analiz etme yeteneğinin iyi olduğu belirtilmiştir (11). *Sorumlu yazar, Uzman Hemşire, İstanbul Üniversitesi Tıp Fakültesi Hastanesi Genel Cerrahi AD, İstanbul Orcid: https://orcid.org/00000001-8023-9684 E posta: sadiesra8755@gmail.com ** Dr. Öğretim Üyesi, Maltepe Üniversitesi Hemşirelik Yüksekokulu Halk Sağlı̆̆ Hemşireliği Anabilim Dalı, İstanbul Orcid: https://orcid.org/0000-0001-9972-3273 
Araştırma

Hemşirelerin; KDU ile ilgili bilgi seviyelerini arttırmaları, becerilerini geliştirmeleri, araştırmaları eleştirel değerlendirebilmeleri, uygulamalarını bilimsel temellere dayandırabilmeleri için sahada KDU kültürünün oluşturulması sağlanmalıdır. Bunun için KDU'ların, hemşirelik öğretiminde derslere entegre edilmesine, klinikte hizmet içi eğitimlerin oluşturularak KDU becerilerinin geliştirilmesine ve hemşirelerin bu konuda kendilerine güvenlerinin sağlanmasına gereksinim vardır $(9,10)$. Öğretim stratejileri ve kliniğe entegre olan çok yönlü ve stratejik müdahaleler; KDU’ya yönelik bilgi, beceri ve tutumlarda olumlu gelişmelere yol açarak hasta sonuçlarının iyileşmesini, bakım maliyetlerinin düşmesini ve hemşirelerin iş doyumunun artmasını sağlayacaktır $(12,13)$. Tüm bu bağlamda kanıta dayalı uygulama, hemşirelerin otonomi kazanmaları ve gerekli yetkiyi elde etmelerinde de yeni bir alternatif olmuştur. Bu araştırma ile öncelikli olarak hemşirelerin KDU tutumlarını ve etkileyen faktörler konusunda temel veri sağlanacaktır. Bu veriler klinikte KDU kültürünün geliştirilmesinde hangi konulara ağırlık verilmesi ve hangi hemşirelik grubuna odaklanılması konusunda veri sağlayacaktır. Bu araştırma sonuçlarının benzer konuda çalışma yapan araştırmacılara ve KDU konusunda girişimsel çalışmalara yol gösterici olacağı düşünülmektedir.

Amaç

Bu araştırma ile hemşirelerin KDU'lara yönelik tutumlarının ve tutumlarını etkileyen faktörlerin belirlenmesi amaçlanmıştır.

\section{Yöntem}

\section{Araştırmanın Tipi ve Yeri}

$\mathrm{Bu}$ çalışma tanımlayıcı türde bir araştırmadır.

Araştırmanın Yeri ve Zamanı

Araştırma İstanbul'da bir vakıf üniversitesi hastanesinde Şubat-Nisan 2019 tarihleri arasında yapıldı.

Araştırmanın Evreni/ Örneklemi

Araştırmanın evrenini bir vakıf üniversitesi hastanesinde çalışan 113 hemşire oluşturdu. Araştırmada örneklem seçiminde kriter belirlenmedi. Tüm çalışma evreni araştırmaya dahil edildi. Çalışma, araştırmaya katılmayı kabul eden 92 hemşire ile \%81 katılım oranıla tamamlandı.

\section{Veri Toplama Araçları}

Araştırma verileri, hemşirelerin tanıtıcı bilgilerini içeren 10 soruluk "Sosyodemografik form” ve "Kanıta Dayalı Hemşireliğe Yönelik Tutum Ölçeği” ile elde edildi.

Sosyodemografik Form: Araştırmacılar tarafından geliştirilmiştir. Yaş, cinsiyet, öğrenim düzeyi, çalışma süresi, bilimsel dergilere üyelik, mesleki derneklere üyelik, mesleki toplantılara katılım, öğrenim döneminde KDU dersi alma durumu, hizmet içi eğitim alma durumu, bilimsel araştırmalara katılma durumu olmak üzere on sorudan oluşturuldu.

Kanıta Dayalı Hemşireliğe Yönelik Tutum Ölçeği (KDHYTÖ): Ölçek 2011 yılında İspanya'da Ruzafa-Martinez, Lopez-Ibaorra ve Madrigal-Torres tarafindan geliştirilmiştir (14). Ölçeğin ülkemizdeki geçerlilik ve güvenilirlik çalışması Ayhan, Kocaman ve Bektaş (2015) tarafından yapılmıştır (15). Ölçek 15 maddeden ve üç alt boyuttan oluşmaktadır. Maddelerin sekizi olumlu $(1,2,5,7,9,11,13$ ve 14 . maddeler), yedisi olumsuz $(3,4,6,8,10,12$ ve 15 .maddeler) ifade içermekte; olumsuz maddeler ters çevrilerek kodlanmaktadır. Ölçek, beşli likert tipindedir. Ölçekten en düşük 15, en yüksek 75 puan alınmaktadır. Ölçeğin kesme noktası yoktur. Ölçekten yüksek puan alınması kanıta dayalı hemşireliğe yönelik tutumun olumlu olduğunu göstermektedir. KDHYTÖ’nin alt boyutlarından, “Kanıta Dayalı Hemşireliğe Yönelik İnanç ve Beklentiler” alt boyutu; hemşirelerin klinik çalışmalarda kanıta dayalı hemşireliğin yararları ile ilgili inanç ve beklentilerine ilişkin maddeleri içermektedir $(1,2,7,9,11,13$ ve 14. maddeler). "Kanıta Dayalı Hemşirelikle ilgili Duygular” alt boyutu; kanıta dayalı hemşireliğe verilen önem boyutunu, klinik uygulamalardaki kullanım yararlarını ve hemşirelerin kanıta dayalı hemşirelikle ilgili duygularına yönelik maddeleri içerir (4,8,10,15. maddeler). "Kanıta Dayalı Uygulama Niyeti” alt boyutu; kanıta dayalı uygulamaları yapma davranışları veya niyetleri, algılanan engelleri, iş yükü ve eğitim için ayrılan sürenin kanıta dayalı hemşirelik için kullanılmasına ilişkin maddeleri içerir $(3,5,6,12$. maddeler). Ölçegin güvenilirlik katsayısı $\alpha=.86$ 'dır. Alt boyut güvenilirlik katsayıları: İnanç alt boyutu için $\alpha$ $=.86$, uygulama niyeti alt boyutu için $\alpha=.63$, duygular alt boyutu için $=.70$ 'tir.

\section{Verilerin Toplanmast}

“Sosyodemografik form” ve "Kanıta Dayalı Hemşireliğe Yönelik Tutum Ölçeği”” Şubat-Nisan 2019 tarihleri arasında bir vakıf hastanesinde çalışan ve araştırmaya katılmayı kabul eden tüm hemşirelere dağıtıldı. Araştırmacı hemşireleri yaklaşık 10 dakika uygun ortamda yalnız bıraktı ve anketler araştırmacı tarafından toplandı.

\section{Verilerin Değerlendirilmesi}

Araştırmaya yönelik veriler analiz edilirken SPSS (Statistical Package For Social Sience) 24.0 paket programı kullanıldı. Verilerin analizinde tanımlayıcı veriler için frekans kullanıldı, veriler normal dağılmadığından iki grubun verilerinin karşılaştırılmasında ise $Z$ testi ikiden fazla grubun karşılaştırılmasında Kruskal Wallis testi kullanıldı. Farkın hangi gruptan kaynaklandığını bulmak için $\mathrm{p}$ anlamlılık değeri, ikili grup karşılaştırmalarında $\mathrm{p}<0.05$, ikiden fazla grup karşılaştırmasında $\mathrm{p}$ anlamlılık değeri Benferroni düzeltme analizi ile $(\mathrm{p}<.0,008)$ kabul edildi.

\section{Araştırmanın Etik Yönü}

Araştırma için girişimsel olmayan araştırmalar etik kurulundan 17/01/2019, 2019/01-01 karar nolu ve etik kurul izni alındı. Çalışmanın yürütüleceği İstanbul'daki bir vakıf üniversitesinden izin alındı. Araştırmaya katılmayı kabul eden hemşirelerden yazılı onam alındı. Kanıta Dayalı Hemşireliğe Yönelik Tutum Ölçeğini Türkçe’ye uyarlayan yazardan izin alındı.

\section{Bulgular}

Çalışmaya katılan hemşirelerin \%82.6'sı kadın, \%43.3'ü lise mezunu ve \%35.9'unun ise çalışma süresi 2-5 yıldır. Hemşirelerin \%91.3'ü bilimsel yayınları takip etmemektedir, \%88'i mesleki derneğe üye değildir, \%81.5'i mesleki bilimsel toplantıya katılmaktadır, \%53.3'ü KDU’ya yönelik ders almamıştır, \% 62'si KDU’ya yönelik hizmet içi eğitim almamıştır ve \%88'i bilimsel araştırmaya katılmamıştır (Tablo 1). 
Araştırma

Tablo 1'de hemşirelerin sosyodemografik özellikleri ile kanıta dayalı uygulamalara yönelik tutum ölçeği puan ortalamalarının karşılaştırılmasına yönelik sonuçlar verilmiştir. Çalışmaya katılan hemşirelerin sosyodemografik özellikleri ile KDHYTÖ puan ortalamaları karşılaştırıldığında; öğrenim düzeyi, çalışma süresi, öğrenim döneminde KDU' ya yönelik ders alma, bilimsel araştırmaya katılma durumları arasında anlamlı bir fark olduğu sonucuna ulaşılmıştır. İkiden fazla değişkenin olduğu gruplarda farklılığın hangi gruplardan oluştuğunu belirlemek için post hoc Benferroni testi kullanılmıştır. (Tablo 1).

Tablo 1. Sosyodemografik Özellikler ile Hemşirelerin Kanıta Dayalı Uygulamalara Yönelik Tutum Ölçeği Puan Ortalaması ile Karşılaştırılması ( $\mathrm{N}=92)$

\begin{tabular}{|c|c|c|c|c|c|}
\hline Tanımlayıcı Özellikleri & $\mathbf{n}$ & $\%$ & $\begin{array}{l}\text { HKDUYTÖ } \\
\text { Puan Ortalaması } \\
\text { X } \pm \text { SS }\end{array}$ & $\begin{array}{l}\text { Test } \\
(\mathrm{Z} / \mathrm{KW})\end{array}$ & $\mathbf{p}$ \\
\hline \multicolumn{6}{|l|}{ Cinsiyet * } \\
\hline Kadin & 76 & 82.6 & $51.95 \pm 5.61$ & -.0987 & .135 \\
\hline Erkek & 16 & 17.4 & $51.33 \pm 5.1$ & & \\
\hline \multicolumn{6}{|l|}{ Öğrenim düzeyi*** } \\
\hline Lise $^{a}$ & 40 & 43.3 & $49.91 \pm 4.12$ & 1.896 & .002 \\
\hline Ön lisans ${ }^{b}$ & 24 & 26.3 & $49.01 \pm 3.75$ & & \\
\hline Lisans $^{c}$ & 20 & 21.7 & $51.08 \pm 4.08$ & & $\mathbf{d}>\mathbf{a}, \mathbf{b}, \mathbf{c}$ \\
\hline \multirow[t]{2}{*}{ Lisansüstü ${ }^{\mathrm{d}}$} & 8 & 8,7 & $52.62 \pm 4.25$ & & $\mathbf{c}>\mathbf{a}, \mathbf{b}$ \\
\hline & & & & & $\mathbf{a}>\mathbf{b}$ \\
\hline \multicolumn{6}{|l|}{ Çalışma süresi** } \\
\hline $0-12$ ay $^{a}$ & 23 & 25.0 & $51.89 \pm 4.91$ & & \\
\hline $2-5 \mathrm{y}_{1}{ }^{\mathrm{b}}$ & 33 & 35.9 & $51.07 \pm 4.21$ & 7.088 & .003 \\
\hline $6-10 \mathrm{y}_{11}^{\mathrm{c}}$ & 20 & 21.7 & $51.12 \pm 4.86$ & & \\
\hline \multirow[t]{3}{*}{$11-15{\mathrm{y} 1 l^{\mathrm{d}}}$} & 16 & 17.4 & $50.31 \pm 4.97$ & & $\mathbf{a}>\mathbf{b}, \mathbf{c}, \mathbf{d}$ \\
\hline & & & & & b $>\mathbf{d}$ \\
\hline & & & & & c>d,b \\
\hline \multicolumn{6}{|c|}{ Bilimsel yayınları takip etme* } \\
\hline Evet & 8 & 8.7 & $51.57 \pm 5.08$ & -.218 & .932 \\
\hline Hayır & 84 & 91.3 & $51.01 \pm 4.98$ & & \\
\hline \multicolumn{6}{|l|}{ Mesleki derneğe üyelik* } \\
\hline Evet & 11 & 12 & $51.06 \pm 5.11$ & -2.584 & .059 \\
\hline Hayır & 81 & 88 & $51.01 \pm 5.02$ & & \\
\hline \multicolumn{6}{|c|}{ Mesleki bilimsel toplantılara katılım* } \\
\hline Evet & 75 & 81.5 & $51.18 \pm 4.48$ & -2.78 & .085 \\
\hline Hayır & 17 & 18.5 & $51.01 \pm 4.27$ & & \\
\hline \multicolumn{6}{|l|}{ KDU dersi almak* } \\
\hline Evet & 43 & 46.7 & $52.04 \pm 5.09$ & -3.167 & .005 \\
\hline Hayır & 49 & 53.3 & $51.01 \pm 5.12$ & & \\
\hline \multicolumn{6}{|c|}{ KDU'ya yönelik hizmet içi eğitim almak* } \\
\hline Evet & 35 & 38 & $51.51 \pm 5.13$ & -.155 & .085 \\
\hline Hayır & 57 & 62 & $50.89 \pm 5.028$ & & \\
\hline \multicolumn{6}{|c|}{ Bilimsel araştırmaya katılmak* } \\
\hline Evet & 11 & 12 & $52.01 \pm 5.008$ & -2.698 & .001 \\
\hline Hayır & 81 & 88 & $50.94 \pm 5.16$ & & \\
\hline
\end{tabular}

*Z Testi, **KW: Kruskal Wallis, X: Ortalama, SS: Standart Sapma, KDHYT: Kanıta Dayalı Hemşireliğe Yönelik Tutum Ölçeği, $\mathrm{p}<.05$ (ikili karşılaştırmalarda), $\mathrm{p}<0.008$ (İkiden fazla grup karşılaştırmasında Benferroni p düzeltmesi) 
Hemşirelerin KDHYTÖ puan ortalaması $51.33 \pm 5.18$ 'dir. “KDH Yönelik İnanç ve Beklentiler” alt boyutu puan ortalamas1 $30.51 \pm 4.36$ 'dır. "KDU Niyeti” alt boyutu puan ortalamas1 $12.69 \pm 2.65$ 'dir. "KDH ile İlgili Duygular" alt boyutu puan ortalamas1 $8.13 \pm 3.70$ 'tir (Tablo 2).

\section{Tablo 2. Hemşirelerin Kanıta Dayalı Hemşireliğe Yönelik Tutum Ölçeği ve Alt Boyutları Puan Ortalamaları (N=92)}

\begin{tabular}{|c|c|c|c|}
\hline Ölçek Toplam grupları & Alt ve üst değerler & $\mathrm{X} \pm \mathrm{SS}$ & (Min-Max) \\
\hline KDHY İnanç ve Beklentiler & $7-35$ & $30.51 \pm 4.36$ & $(17-33)$ \\
\hline KDU Niyeti & $4-20$ & $12.69 \pm 2.65$ & $(7-19)$ \\
\hline KDH ile İlgili Duygular & $4-20$ & $8.13 \pm 3.70$ & $(5-14)$ \\
\hline KDHYTÖ Toplam Puan & $15-75$ & $51.33 \pm 5.18$ & $(28-62)$ \\
\hline
\end{tabular}

KDHYTÖ: Hemşirelerin Kanıta Dayalı Uygulamalara Yönelik Tutum Ölçeği, KDU: Kanıta Dayalı Uygulama, KDH: Kanıta Dayalı Hemşirelik

\section{Tartışma}

Son yıllarda sağlık hizmetlerinde önemli gelişmelerden biri KDU’nun kullanımı ve geliştirilmesidir (16). Yapılan bu araştırmada hemşirelerin KDHYTÖ puan ortalamasının hemşirelerin KDU'ya yönelik tutumlarının $51.33 \pm 5.18$ ile orta düzeyde olduğu söylenebilir. Literatürü incelediğimizde Durmuş ve arkadaşlarının (2017) araştırmasında hemşirelerin KDHYTÖ puan ortalaması $53.75 \pm 9.39$ ile orta düzeyde bulunmuştur (17). Küçükoğlu ve arkadaşlarının (2017) yaptıkları çalışmada, hemşirelerin KDHYTÖ toplam puan ortalaması $57.03 \pm 9.06$ olarak saptanmıştır (18). Yılmaz ve arkadaşlarının (2017) araştırmasında hemşirelerin KDHYTÖ puan ortalaması 57.14 \pm 8.27 'dir (19). Tüm bu araştırma sonuçları ile karşılaştırdığımızda araştırma sonucunun literatüre göre düşük olması, bu araştırmanın tek bir hastanede ve hemşirelerin \%69.6'sının öğrenim düzeyinin lise ve ön lisans seviyesinde olmasından kaynaklandığı düşünülebilir. Hastanelerde kanıt temelli uygulamaların daha çok yaygınlaşması eğitim seviyesinin lisans ve üstü seviyelerde olmasıyla doğrudan ilişkilidir.

Öğrenim düzeyi, inanç, klinik deneyim, KDU’ya duyulan güven, örgütsel yapı, liderlik vasfı ve var olan kaynaklara ulaşım gibi faktörler KDU ile ilişkili kavramlardır (20). Araştırmada KDHYTÖ inanç ve beklentiler alt boyutu ortalaması 30.51 \pm 4.36 olarak bulunmuştur. Yılmaz ve arkadaşlarının (2017) araştırmasında ise KDHYTÖ alt boyutları incelendiğinde en yüksek puanı “KDH'ye yönelik inanç ve beklentiler” alt boyutundan (27.08 \pm 4.43$)$ aldıkları, yine Yılmaz ve arkadaşlarının (2019) diğer bir çalışmasında en düşük puanı ise "KDU niyeti” alt boyutundan (10.55 \pm 1.93$)$ aldıkları görülmektedir (19-21). Araştırma sonucumuzda KDU inanç alt boyutu $(30.51 \pm 4.36)$ yüksek olmasına rağmen KDU niyeti alt boyutu (12.69 \pm 2.65$)$ puan ortalaması orta düzeyde bulunmuştur. Scurlock-Evans ve arkadaşları (2014) tek başına KDU'ya yönelik inanç ve tutumları değerlendirmenin, KDU'ya yönelik davranışlarda değişikliğe yol açamayacağını belirtmişlerdir (13). Niyet, davranışa dönüştürmede önemli bir belirleyicidir. Ancak bu çalışmada hemşirelerin niyetlerinin düşük olması, çalıştıkları kurumda KDU'ya yönelik hizmet içi eğitim, liderlik, kaynaklara erişim, araştırmalara katılım, iyi uygulama örnekleri görmeme, lisans düzeyi öğrenimine sahip hemşirelerin az olması gibi durumların bu sonucu etkilemiş olabileceği düşünülmektedir. Araştırma sonucumuzda KDH ile ilgili duygular alt boyutu puan ortalaması $8.13 \pm 3.70$ ile orta düzeyde bulunmuştur. Daştan ve Hintistan'ın (2018) araştırmasında ise kanıta dayalı hemşirelikle ilgili duygular alt boyut puan ortalaması $15.28 \pm 3.59$ olarak saptandığı görülmektedir. Kanıta dayalı hemşireliğe yönelik tutum ölçeği duygular alt boyutu; kanıta dayalı hemşireliğe verilen önemi ve hemşirelerin konuyla ilgili duygularını içermektedir (22).

Araştırma sonucunda, eğitim düzeyi arttıkça KDHYTÖ puanlarında artış olduğu bulunmuştur. Lisansüstü eğitim alan hemşirelerin KDHYTÖ puan ortalaması, lise, ön lisans ve lisans mezunlarından anlamlı derecede farklı bulunmuştur. Lise mezunu hemşirelerin puan ortalaması ön lisans mezunu olan hemşirelerden daha yüksek çıkmıştır. Bu durum KDU’ya yönelik yeterli bilgiye sahip olmamaya bağlı daha pozitif tutum gösterme nedeni ile ortaya çıkmış olabilir. Yurt ve arkadaşları (2019) lisansüstü eğitim alan ve kliniklerde çalışan hemşirelerle yaptıkları araştırmada, hemşirelerin klinik uygulamalarının KDU’ya yönelik olmadığını belirtmişlerdir (24). Çalışmamızda bilimsel toplantılara katılan hemşirelerin KDUYTÖ puan ortalamaları anlamlı derecede yüksektir. Mulenga ve arkadaşlarının (2017) araştırmasında hemşirelerin KDU ile ilgili ortalama bilgiye sahip olduğu, tutumlarının olumlu olduğu, ancak KDU’larının çok düşük olduğu sonucuna varmışlardır (25). Bu sonuçlar; olumlu tutumların, davranışa dönüştürmede itici kuvvet olabileceğini ancak uygulamaya geçirilebilmenin kesin şartı olmadığını ortaya koymuştur. Olumlu tutumların davranışa dönüşebilmesi için; klinik alanlarda uygulama ile ilgili protokollerin geliştirilmesine, klinik alanda KDU mentörlerine, yönetimsel desteğe, araştırma kaynaklarına erişime, lisans ve üzeri öğrenim düzeyine sahip hemşirelerin daha fazla kliniklerde görev almalarına ve hizmet içi eğitimlerle desteklenmelerine ihtiyaç olduğu düşünülmektedir.

Bu araştırmada, KDHYTÖ puan ortalaması en yüksek çalışma süresi bir yıl ve altında olan hemşirelerde, KDHYTÖ puan ortalaması en düşük 11-15 yıl arasında çalışan hemşirelerde bulunmuştur. Yılmaz ve arkadaşlarının (2018) araştırmasında 10 yıl üzerinde çalışan hemşirelerin KDH'ye yönelik tutumlarının daha olumsuz olduğu (21), Breimaier ve arkadaşlarının (2011) çalışmasında ise altı yıldan daha az çalışma süresi olanların, KDU’ya yönelik tutumlarının daha olumlu olduğu belirlenmiştir (23). Bu durum yeni mezun olan hemşirelerin gelişime daha açık ve KDU konusunda daha duyarlı olduklarını düşündürmektedir. Klinik alanlarda KDU'ya yönelik hizmet içi eğitim programlarının olmasının ve KDU’ya mentörlük sisteminin geliştirilmesinin, KDU’lara yönelik etkin liderlik sağlanmasının bu engeli ortadan kaldırabileceği düşünülmektedir. 
Çalışmamızda, eğitim hayatında KDU dersi almış olanların almayanlara göre KDHYTÖ puan ortalaması anlamlı düzeyde yüksek olduğu saptanmıştır. Karataş ve arkadaşlarının (2019) hemşirelerin öğretim hayatında KDU dersi almış olmalarının kanıta dayalı tutumlarını etkilediğini belirlemişlerdir (26). Şenyuva (2016) araştırmasında, üniversite-klinik alan işbirliğinin sağlanması gerektiğini ve akademisyen hemşireler ile klinikte çalışan hemşirelerin bu işbirliğinde aktif görev almalarını önermiştir (27). Hemşirelik öğretim programında KDU konusunda derslere yer verilmesi ve klinik eğitimlerde pekiştirici çalışmaların yapılması, hemşirelerin KDU'lara yönelik bakış açısının gelişmesine katkı sağlayabilir. KDU ile ilgili sorumluluk öğretim döneminde akademisyenler, uygulamada ise klinisyenlerin ve yönetici hemşirelerin sorumluluğundadır. $\mathrm{Bu}$ sorumluğu taşıyan uzman ve kurumların birbirleri ile işbirliği içinde ve bir an önce çalışmaya başlanmasına ihtiyaç olduğu düşünülmektedir.

Çalışmamızda, hizmet içi eğitim alan hemşirelerin KDHYTÖ puan ortalaması almayanlara göre yüksek olmasına rağmen, istatistiksel açıdan anlamlı bir fark bulunmamıştır. Bu sonucun, lisansüstü öğrenim yapanların sayısının daha az olmasından kaynaklanmış olabileceği düşünülmüştür. Çalışmamızda mesleki derneğe üye olan ve olmayanların KDHYTÖ puan ortalamaları arasında fark bulunmamıştır. Mesleki derneğe üye olmanın KDU'ları hayata geçirmede etkili olmadığı düşünülebilir. Ancak mesleki örgütlerin, KDU konusunda teşvik edici politikaların oluşturulmasında önemli rolleri vardır. Bunun hayata geçirilmesi için hemşirelik derneklerinin ve hemşirelik örgütlerinin ortak bir çalışma yürütmesi yararlı olabilir.

Çalışmamızda, hemşirelerin çoğu bilimsel yayınları takip etmediği ancak mesleki bilimsel toplantılara katılmadığı belirlenmiştir. Mesleki bilimsel toplantılara katılma durumları ile KDHYTÖ toplam puan ortalamaları arasında ise anlamlı fark bulunmamışıır Hemşirelerin KDU'ları klinik alanda hayata geçirebilmeleri için bilimsel araştırmalara yönelik olumlu tutum sergilemeleri gerektiği bildirilmektedir (28). Daştan ve Hintistan'ın (2018) araştırmasında, hemşirelerin \%56.3'ünün mesleki yayınları takip ettiği ve \%62.5'inin bilimsel toplantılara katılmadığı belirlenmiştir (22). Yılmaz ve arkadaşlarının (2017) araştırmasında, hemşire grubunun \%39.8'inin bilimsel toplantılara katıldığı ve sadece \%.32.8'inin mezuniyet sonrası hemşirelik ile ilgili bilimsel araştırma yaptığı belirlenmiştir (19). Wang ve arkadaşlarının (2013) araştırmasında, hemşirelerin \%83.1'inin araştırma deneyiminin olmadığı ve \%60.7'sinin KDU konusunda hiçbir fikrinin olmadığı sonucuna varmışlardır (29). Demir ve arkadaşlarının (2012) yaptıkları araştırmada, hemşirelerin \%54.9'unun bilimsel bir etkinliğe katılmadığ ve hemşirelerin \%62.2'sinin bilimsel araştırmalardan haberlerinin dahi olmadığı belirlenmiştir (30). Yılmaz ve arkadaşları (2018) hemşirelerin \%59.7'sinin uygulamada KDU'ları kullanmadığını ve \%55.9'unun kanıtlara ulaşabilecekleri kaynakları bilmediğini belirlemişlerdir (21). Tüm bu sonuçlar; hemşirelerin bilimsel araştırma yapma, araştırmaların yayın süreci, kaynaklara erişim ve mesleki otonomi konusundaki yeterliliklerini geliştirmeye yönelik desteklenmeye ihtiyaçları olduğunu ortaya koymaktadır.

\section{Kisıtlılıklar}

Araştırmada kullanılan veri toplama aracı sosyodemografik bilgileri içeren anket formu ve kanıta dayalı hemşireliğe yönelik tutum ölçeği ile sınırlıdır. Araştırma bir vakıf üniversitesi hastanesinde çalışan hemşireler ile sınırlıdır.

\section{Sonuçların Uygulamada Kullanımı}

Hemşirelerin kanıta dayalı hemşireliğe yönelik tutumlarını belirlemeye yönelik yaptığımız bu çalışmada, hemşirelerin KDHYTÖ puan ortalaması orta düzeyde bulunmuştur. KDHYTÖ inanç ve beklentiler alt boyutu puan ortalamasının yüksek bulunması, hemşirelerin kanıt temelli uygulamalara inandıklarını göstermektedir. Bunun yanı sıra KDHYTÖ uygulama niyeti alt boyutunun orta düzeyde bulunması ise KDU'ya yönelik yüksek düzeydeki inancın, davranış değişikliğine yol açmadığı belirlenmiştir. Sosyodemografik özellikler ve KDHYTÖ puan ortalaması karşılaştıııldığında; çalışma süresi bir yıl ve daha az olanların, lisansüstü ögrrenim düzeyine sahip olanların, öğretim hayatında KDU dersi almış olanların ve daha önce bilimsel araştırmaya katılmış olanların KDHYTÖ puan ortalaması anlamlı düzeyde yüksek olduğu belirlenmiştir. Araştırma sonuçları göz önüne alındığında; hemşirelik eğitim müfredatında KDU derslerine yönelik ders eklenmesi veya derslerde bu konuya yönelik ağırlık verilmesi, hemşirelerin araştırma süreçleri içinde yer almalarının desteklenmesi, akademik ve klinik alanda çalışanların ortak çalışmalarını geliştirici firsatların yaratılması, hemşirelere yönelik hizmet içi eğitim programlarında KDU'lara yer verilmesi, hastanelerde KDU komitelerinin kurulması ve mentör hemşirelerin yetiştirilmesi, hastanelerin lisans ve lisansüstü hemşireleri daha fazla istihdam etmeleri, bilimsel kongrelerde KDU konusunda eğitim programlarının oluşturulması ve KDU'ları geliştirmeye yönelik girişimsel araştırma çalışmalarının yapılması önerilebilir.

\section{Bilgilendirme}

Yazarların katkı oranı beyanı şöyledir: Fikir/kavram EŞŞ, SY; tasarım EŞŞ, SY; danışmanlık SY; veri toplama ve işleme; EŞŞ; analiz ve yorum EŞŞ, SY; kaynak taraması EŞŞ, SY; makalenin yazımı EŞŞ, SY; eleştirel düşünme EŞŞ, SY; araştımanın bütçesi; EŞŞS.

Araştırma ile ilgili herhangi bir projeden ya da firmadan destek alınmamıştır. Araştırma bütçesi araştırmacılar tarafindan karşılanmıştır. Yazarlar arasında herhangi bir çıkar çatışması yoktur. Sorumlu olduğumuz araştırmada herhangi bir firma ile çıkar çatışması yoktur.

Araştırmanın yapılabilmesi için bir üniversitenin girişimsel olmayan araştırmalar etik kurulundan 17/01/2019 tarihinde, 2019/01-01 nolu karar alınmıştır. 


\section{Kaynaklar}

1. Andrae B, Aune AG, Braend JA. Embedding evidence-based practice among nursing undergraduates: Results from a pilot study. Nurse Educ Prac 2016; 18: 30-5.

2. Melnyk BM, Fineout-Overholt E, Gallagher-Ford L, Kaplan L. The state of evidence-based practice in US nurses: Critical implications for nurse leaders and educato. J Nurs Adm 2012; $\underline{42(9): 410-417 .}$

3. Kücükkaya P.G. Psikiyatri hemșireliğinde kanıta dayalı uygulama. Psikiyatri Hemșireliği Dergisi 2010; 1(3): $128-132$.

4. Tanık M, Sarıbay E, Baba D. Hemşirelerin ilaç uygulama adımlarına uyumu ve sağlık kalitesindeki yeri. IJSHS 2018; 5(17): 230-240.

5. Türkiye Sağlık Bakanlığı Hemşirelik Yönetmeliği, (2010. 8. Mart). T.C. Resmi Gazete, Sayı: 27515. URL: http://www.resmigazete.gov.tr/eskiler/2010/03/20100308-4.htm/

6. Akbulut Y, Bayın G. Kanıta dayalı yaklaşım ve sağlık politikası. Ankara Sağlık Bilimleri Dergisi 2012; 1(2): 115-132.

7. Harvey G, Gifford W, Cummings G, Kelly J, Kislov J, Kitson A, Pettersom L et al. Mobilising evidence to improve nursing practice: A qualitative study of leadership roles and processes in four countries, Int J Nur Stud 2019; 90: 21-30.

8. Özer KE, Çakmak S, Kapucu S, Koç M, Kahveci R. Hemşirelik öğrencilerinin kanıta dayalı hemşirelik uygulamalarına ilişkin farkındalıklarının belirlenmesi. Hacettepe Üniversitesi Hemşirelik Fakültesi Dergisi 2017; 4(2): 1-12.

9. Young T, Rohwer A, Volmink J, Clarke M. What are the effects of teaching evidence-based health care (EBHC)? Overview of systematic reviews. PLoS One [online]. https://journals.plos.org/plosone/article?id=10.1371/journal.pone.0086706. 05 May1s 2020

10. Yılmaz M, Gürler H. Hemşirelerin kanıta dayalı uygulamaya ilişkin görüşleri. F.N.H.Y.O. Dergisi 2017; $25(1)$ : 1-12.

11. Dugan JE. Keeping You in the Know": The Effect of an Online Nursing Journal Club on Evidence-Based Knowledge Among Rural Registered Nurses. CIN 2018; 36(8): 398-405. URL: https://insights.ovid.com/crossref?an=00024665-900000000-99452. 25.Şubat 2019

12. Ayhan Y, İntepeler SŞ. Yakın işbirliğine dayalı ileri araştırma ve klinik uygulama modeli: Kanıta dayalı düşme önleme stratejilerinin kullanımı. DEUHFED [online]. 2015; $8(3)$ : $195-202 . \quad 7 \quad$ May1S $2020 \quad$ URL: http://www.deuhyoedergi.org/index.php/DEUHYOED/article/view/161

13. Scurlock-Evans L, Upton P, Upton D. Evidence-based practice in physiotherapy: A systematic review of barriers, enablers and interventions. Journal Article 2014; 100: 208-219.

14. Ruzafa-Martinez M, Lopez-Iborra L, Madrigal- Torres M. Attitude towards evidence-based nursing questionnaire: Development and psychometric testing in Spanish community nurses. J. Eval. Clin. Pract 2011; 17(4): 664-670.

15. Ayhan Y, Kocaman G, Bektaş M. Kanıta dayalı hemşireliğe yönelik tutum ölçeği’nin Türkçe'ye uyarlanması: Geçerlik ve güvenirlik çalışması. HEAD 2015; 17(2-3): 21-35.

16. Mackey A, Bassendowski S. The history of evidence-based practice in nursing education and practice. J Prof Nurs 2017; 33(1): 51-55.

17. Durmuş M, Gerçek A, Çiftci N. Sağlık çalışanlarının problem çözme becerilerinin kanıta dayalı tutum algıları üzerindeki etkisi. ASBIDER 2017; 5(52): 648-661.

18. Küçükoğlu S, Bükecik T, Aytekin A, Çelebi A. Acil birimlerde çalışan hemşirelerin adli vakayla ilgili yaklaşımları ve kanıta dayalı uygulamaları. Türkiye Klinikleri Journal of Forensic Medicine and Forensic Sciences. 2017; 14(1): 1-8.

19. Yılmaz E, Çeçen D, Aslan A, Kara H, Kızıl TH, Mutlu S. Attitudes towards evidence-based nursing and perceptions of obstacles in using research of nurses working in surgical clinics. HEAD 2017; 15(4): 235-241.

20. Boström AM, Rudman A, Ehrenberg A, Gustavsson PJ, WallinL. Factors associated with evidence-based practice among registered nurses in Sweden: A national cross-sectional study. BMC Health Services Research [online]. 2013; 13-165. URL: https://bmchealthservres.biomedcentral.com/track/pdf/10.1186/1472-6963-13-165. 10 Şubat 2019

21. Yılmaz D, Düzgün F, Dikmen Y. Hemşirelerin kanıta dayalı hemşireliğe yönelik tutumlarının incelenmesi, ACU Sağlık Bil $\begin{array}{lllll}\text { Derg } & \text { [online]. } & \text { 2018; } & \text { 10(4): } & \text { URL: }\end{array}$ http://acibadem.dergisi.org/uploads/pdf/pdf_AUD_519.pdf. 01 Ocak 2019

22. Daştan B, Hintistan S. Dahiliye kliniklerinde çalışan hemşirelerin kanıta dayalı hemşireliğe yönelik tutumlarının belirlenmesi: Kırsal bölge örneği. Ordu Üniversitesi Hemşirelik Çalışmaları Dergisi 2018; 1(1): 1-9.

23. Breimaier HE, Halfens RJG, Lohrmann C. Nurses' wishes, knowledge, attitudes and perceived barriers on implementing research findings into practice among graduate nurses in Austria. J Clin Nurs 2011; 20(11-12): 1744-56.

24. Yurt S, Kolaç N, Şadi E. Postgraduate nursing students'opinions on evidence-based practices: Qualitative study. EvidenceBased Practices in Nursing, International Student Congress; 26-27 March 2019; Istanbul

25. Mulenga C, Naidoo RJ. Nurses' knowledge, attitudes and practices regarding evidence-based practice in the prevention of mother-to-child transmission of HIV programme in Malawi. Curationis [online]. 2017; 40(1): 1-8. URL: https://europepmc.org/backend/ptpmcrender.fcgi?accid=PMC6091589\&blobtype=pdf. 05 Nisan 2020

26. Karataş BG, Atasoy S, Şahin S. Hemşirelerin kanıta dayalı uygulamalarına yönelik farkındalık ve tutumlarının değerlendirilmesi. 2. Uluslararası Hemşirelik ve İnovasyon Kongresi; 4-5 Mayıs 2018; İstanbul

27. Şenyuva E. Hemșirelik eğitimi ve kanıta dayalı uygulamalar. İ̈̈FNHD 2016; 24(1): 59-65.

28. Halabi JO. Attitudes of Saudi nursing students toward nursing research. Saudi J HealthSci 2016; 5: 118-124.

29. Wang LP, Jiang XL, Wang L, Wang GR, Bai YJ. Barriers to and facilitators of research utilization: A survey of registered nurses in China. Plos One [online]. 2013; 8(11): $1-9 . \quad$ URL: https://www.ncbi.nlm.nih.gov/pmc/articles/PMC3843703/pdf/pone.0081908.pdf. 5 Nisan 2019

30. Demir Y, Ak B, Bilgin NÇ, Efe H, Albayrak E, Çelikpençe Z ve ark. Hemşirelik uygulamalarında araştırma sonuçlarının kullanımındaki engeller ve kolaylaştırıcı faktörler. Çağdaş Tıp Dergisi 2012; 2(2): 94-101. 